УДК 341.9

DOI https: / / doi.org/10.32837/yuv.v0i1.2095

\author{
О. Заставна, \\ кандидат юридичних наук, \\ викладач \\ Галицького коледжу імені В'ячеслава Чорновола
}

\title{
РЕГУЛЮВАННЯ АЛІМЕНТНИХ ВІДНОСИН У ТРАНСКОРДОННОМУ ПРОСТОРІ
}

Останнім часом у зв'язку з дедалі більшою кількістю шлюбів, які укладаються 3 іноземними громадянами та особами без громадянства, особливої актуальності набули проблеми стягнення аліментів у разі проживання подружжя в різних державах.

Поняття аліментів та виконання аліментних зобов'язань у міждержавному просторі досліджені у наукових доробках Л. Галенської, С. Муратової, О. Костюченко та інших. Разом із тим в умовах глобалізації та інтеграції, коли транскордонні шлюби поступово стали невід'ємною частиною сучасного суспільства, $€$ необхідність деталізації вивчення та глибшого аналізу транскордонних аліментних зобов'язань, що зумовило вибір напряму наукового дослідження цієї статті.

Дитина займає особливе становище в правовому суспільстві, що зумовлене ії залежністю від батьків, неповною дієздатністю та іншими причинами. Кожна дитина має право на рівень життя, необхідний для їі фізичного, розумового, духовного, морального i соціального розвитку (ст. 27 Конвенції про права дитини [8]). Батьки або інші особи, які виховують дитину, повинні забезпечити умови життя, необхідні для іiі розвитку, в межах своїх здібностей і фінансових можливостей.
В умовах глобалізації та інтеграціï транскордонні шлюби поступово стали невід'ємною частиною сучасного суспільства, а тому вимагають до себе нестандартного підходу. Сімейні стосунки в країнах Європи повинні враховувати інтереси кожного суб'єкта таких відносин.

Специфікою аліментних зобов'язань батьків щодо утримання неповнолітніх дітей $€$ виникнення таких правовідносин незалежно від будьяких обставин, у законодавстві закріплений абсолютний характер аліментних обов'язків батьків.

Аліментні зобов'язання щодо дитини можуть набувати різноманітних форм i «ніякої чіткої концепції аліментування не існує». Деякі форми змісту є загальноприйнятими, а інші форми варіюються залежно від законів і правил у конкретній державі. Право дитини на утримання іï як загальне правило прийняте у всьому світі. Стаття 27 Конвенції ООН про права дитини вимагає, щоб обоє батьків виплачували аліменти на свою дитину, і закликає держави-члени підписувати міжнародні угоди, що зобов'язують вживати всіх необхідних заходів для забезпечення відновлення утримання дитини батьками або іншими особами, які відповідають за дитину, як усередині державиучасниці, так і з-за кордону [8]. Хоча 
ці норми і існують, законодавство не завжди дотримується або ж виникають труднощі на етапі примусової реалізації [7].

Є кілька джерел регулювання аліментних зобов'язань у міжнародному приватному праві:

1. Конвенція ООН від 20 червня 1956 року про стягнення за кордоном аліментів, метою якої $€$ спрощення стягнення аліментів, на які особа (позивач), що перебуває на території однієї з Договірних Сторін, заявляє своє право, з іншої особи (відповідача), яка підпадає під юрисдикцію іншої Договірної Сторони. Ця мета досягається через установи й органи - Органи, що передають, i Органи, що приймають. Функції цих органів в Україні відповідно до Інструкції про виконання в Україні Конвенції про стягнення аліментів за кордоном, яка затверджена Наказом Міністерства юстиції України від 29 грудня 2006 року, покладено на Міністерство юстиції України [11].

2. Гаазька конвенція від 24 жовтня 1956 року про право, що застосовується до аліментних зобов'язань стосовно дітей. Передбачає створення країнами, що приєдналися до Конвенціï, агентств, які передають і отримують аліментні виплати. Відповідно до П. 3 ст. 9 Конвенції такі агентства не повинні вимагати ніяких зборів за надані послуги. Розгляд справи має проводитися з дотриманням принципу рівноправності сторін, незалежно від того, громадянами якої держави $€$ сторони, включаючи надання рівних пільг зі сплати судових витрат.

3. Гаазька конвенція від 15 квітня 1958 про визнання та виконання рішень щодо аліментних зобов'язань стосовно дітей.

4. Гаазька конвенція від 02 жовтня 1973 року про визнання і виконання рішень стосовно зобов'язань про утримання. Конвенція застосовується до аліментних зобов'язань, що виникають із сімейних відносин, батьківства чи материнства, шлюбу та щодо позашлюбної дитини. $\mathrm{Y}$ відносинах між державами, які $€$ iї сторонами, Конвенція замінює Конвенцію про право, що застосовується до аліментних зобов'язань стосовно дітей, укладену в Гаазі 24 жовтня 1956 року. На відміну від Конвенції 1956 року, колізійні положення Конвенції 1973 року застосовні як до аліментних зобов'язань стосовно дітей, так і до аліментних зобов'язань стосовно повнолітніх членів сім’і.

Указана конвенція нині підписана п'ятьма державами (включаючи ЄС, США, Україну). Конвенція заміняє у відносинах між державами, які $€$ ï сторонами, Конвенцію $\mathrm{OOH}$ 1956 року про стягнення за кордоном аліментів, Гаазьку конвенцію 1958 року про визнання і виконання рішень щодо аліментних зобов'язань стосовно дітей, Гаазьку конвенцію 1973 про визнання та виконання рішень у сфері аліментних зобов'язань. Метою Конвенції є забезпечення ефективного міжнародного порядку стягнення аліментів на дітей та інших форм утримання сімі за допомогою встановлення універсальної системи взаємодіiі між органами Договірних держав, забезпечення доступності заяв, що подаються стосовно рішень про аліменти, забезпечення визнання та приведення у виконання рішень про виплату аліментів і визначення ефективних заходів для негайного примусового виконання рішень про аліменти [6].

5. Протокол від 23 листопада 2007 року про право, що застосовується до аліментних відносин. Визначає право, що застосовується до аліментних зобов'язань, що виникають із сімейних відносин, походження, шлюбу або спорідненості, включаючи аліментні зобов'язання щодо дитини незалежно від шлюбного стану батьків.

6. Конвенція ООН «Про права дитини» 1989 року.

7. Регламент Європейської ради № 4/2009 «Про юрисдикцію, застосовне право, визнання та виконання 
рішень, а також співробітництво в галузі аліментних зобов'язань». Важливо, що такий регламент передбачає регулювання зобов'язань про сплату аліментів, що виникають із сімейних, батьківських, шлюбних чи родинних відносин [10].

Норми, що регулюють аліментні зобов'язання, здебільшого мають імперативний характер. Багато країн вирішують питання взаємного утримання сім’ $\dddot{1}$ шляхом застосування Гаазької конвенції про право.

Гаазька Конвенція 2007 року забезпечує ефективне стягнення аліментів на дітей та реалізацію інших форм утримання сімі шляхом створення міжнародного співробітництва в країнах Європи, визнання, а також виконання рішень про стягнення аліментів у примусовому порядку, можливість вжиття заходів, у разі яких ці рішення будуть виконуватися досить оперативно і швидко [6].

Крім того, вказана Конвенція застосовується до аліментних зобов'язань, які виникають між батьками і дітьми, які досягли 21 року, а також між подружжям та соціально вразливими особами. Тобто положення Гаазької конвенціі 2007 року є досить широкими і дозволяють ураховувати інтереси великого кола осіб.

У Конвенції 2007 року встановлюється, що держави, до яких надійде звернення 3 проханням забезпечити виплату аліментів дітям їхніх громадян, повинні будуть «застосовувати, принаймні, той самий набір примусових заходів», які застосовуються у випадках, що стосуються виплат аліментів у межах цих держав. Конвенція спростила процедури стягнення аліментів у випадках, коли один з батьків перебуває на території іншої держави і не перераховує щомісячно кошти на утримання дитини [5].

Метою Гаазької конвенції і Гаазького протоколу 2007 року є модернізація чинних у цій сфері міжнародно-правових актів, зокрема Конвенції ООН про стягнення алі- ментів за кордоном (Нью-Йорк 20 червня 1956 року), Гаазької конвенції про право, що застосовується до аліментних зобов'язань (02 жовтня 1973 року) і Гаазької конвенції про право, що застосовується до аліментних зобов'язань стосовно дітей (24 жовтня 1956 року). Першими двома країнами, які ратифікували Гаазьку конвенцію 2007 року, були Албанія і Норвегія. ЄС ратифікував цю конвенцію 09 квітня 2014 року.

Предметом регулювання Гаазької конвенції 2007 року є забезпечення ефективного міжнародного стягнення аліментів на дітей та інших форм утримання сімі, зокрема за допомогою:

1) створення всебічної системи співпраці між державами-учасниками;

2) надання можливості подачі заяв на винесення рішень про встановлення змісту;

3) визнання і примусового виконання рішень про стягнення аліментів;

4) вимоги ефективних заходів, що дозволяють оперативно виконувати рішення про примусове стягнення аліментів.

У ст. 2 Гаазької конвенції 2007 року зазначено, що вона може бути застосована стосовно неповнолітніх осіб, які не досягли 21-річного віку. Однак договірні держави можуть зробити застереження: наприклад, визнати можливість стягнення аліментів на дітей віком до 18 років або старших 21 року. Так, Норвегія заявила, що буде забезпечувати дотримання рішень про аліментні зобов'язання в інтересах дітей, старших 21 року, але не більше, ніж до 25 років. Албанія зумовила можливість примусового виконання аліментних зобов'язань для дітей віком до 25 років за умови відвідування ними середньої школи або університету відповідно до ст. 197 Сімейного кодексу Албаніï. Україна, Чорногорія, Білорусь зробили застереження про зниження віку [2]. 
Будь-яка держава - учасник Гаазької конвенції 2007 року може залишити за собою право обмежити застосування цієї конвенції тільки особами, які не досягли 18-річного віку.

Україна заявила, що вона поширить застосування глав V і VIII Гаазької конвенції 2007 року на стягнення аліментів:

- $з$ батьків на користь дорослих недієздатних;

- $з$ батьків на користь дорослих дітей, які продовжують навчання, до досягнення 23-річного віку;

- 3 дорослих дітей на користь недієздатних батьків.

Бразилія розширює застосування всієї Гаазької конвенції 2007 року за умови застережень до зобов'язань щодо забезпечення змісту, що випливають зі спорідненості, прямого споріднення, шлюбу або близькості, включаючи зобов'язання щодо членів сім'і, які опинилися в скрутному матеріальному становищі [1].

Положеннями Гаазької конвенції 2007 року визначаються:

- зміст загальних і специфічних функцій національних органів договірних держав (ст. 5-6);

- умови вибору і наділення національних органів договірних держав функціями 3 контролю за дотриманням вимог, передбачених Гаазькою конвенцією 2007 року (ст. 4);

- порядок подання та розгляду заяв у національних органах договірних держав з контролю за дотриманням вимог, передбачених Гаазькою конвенцією (ст. 9-12);

- умови обмеження на порушення провадження (гл. 4);

- підстави для визнання і виконання рішення щодо аліментних зобов'язань (гл. 5);

- умови виконання рішень щодо аліментних зобов'язань відповідно до законодавства запитуваної держави (гл. 6).

Розроблений у $\in C$ Регламент про аліменти спрямований на забезпечення ефективного i швидкого відновлення технічного обслуговування, що $є$ ще одним кроком до гармонізації європейського сімейного права. Основна мета Регламенту про аліменти - забезпечити визнання i забезпечення виконання судових рішень без обмеження права будь-якої сторони такого рішення оскаржувати таке рішення у суді держави члена $Є C$, в якій воно було винесене.

Регламент про аліменти застосовується між усіма державами-членами $\in C$, включаючи Великобританію. Регламент про аліменти створює взаємозв'язок між однаковим дотриманням правових норм у разі конфлікту національних законодавств про аліменти, встановлює певні правила, які стосуються визнання та примусового виконання рішень чи аліментних угод.

Якщо суд держави-члена ЄС під час розгляду позову з'ясовує, що у нього відсутні повноваження розглядати позов, він повинен самостійно клопотати про відсутність у нього компетенції розглядати подібного роду суперечки. Право, яке застосовується до зобов'язань зі сплати аліментів, має бути визначене відповідно до Гаазького протоколу 2007 року, у застосуванні певного права може бути відмовлено в разі, якщо наслідки його застосування будуть явно суперечити публічному порядку суду.

Згідно з Регламентом про аліменти, кожна держава - учасник $Є C$ визначає центральний орган влади для виконання обов'язків, покладених на нього. Як і Гаазька конвенція 2007 року, Регламент про аліменти надає федеративним державам або державам, в яких існує кілька правових систем, можливість створювати кілька центральних органів влади. Однак при цьому такі держави повинні призначити певний центральний орган влади, якому може бути адресована будь-яка інформація для передачі у майбутньому до відповідного центрального органу влади в межах зазначеноъ держави [4]

Обов'язок забезпечувати тих, на кого покладено юридичне і моральне зобов'язання аліментування, вкрай 
важливий. 3 переміщенням і міграцією людей як у Європі, так і в усьому світі виникає все більше сімей, члени якої живуть у різних державах. Тому вкрай важливо, щоб існували відповідні і працездатні методи для створення зобов'язань за змістом, а потім забезпечення переказу коштів, особливо з-за кордону [7].

Законодавство Німеччини передбачає наявність обов'язків батьків щодо утримання дітей, які досягли повноліття, і включає у себе кілька категорій:

1. Повнолітні до досягнення 21 року, які не перебувають у шлюбі, проживають з батьками (одним з них) і здобувають загальну шкільну освіту (згідно із § 1603 Цивільного кодексу Німеччини);

2. Особи, які досягли 21 року і отримали загальну шкільну освіту, не проживають з батьками (одним з них) і не в змозі себе утримувати.

При цьому важливим фактом $€ \mathrm{i}$ те, що законодавство Німеччини забезпечує матеріальну підтримку повнолітнім особам, які продовжують своє навчання не тільки за рахунок аліментних зобов'язань їніх батьків, а й за допомогою соціальних виплат [3]. На погашення первинних потреб (проїзд та ін.) виплачується 90 євро повнолітнім, які проживають хоча б з одним з батьків. Такі виплати називаються "Anrechnung der Ausbildungsvergbtung” [3].

Обов'язок щодо утримання покладається на батьків на підставі доведеного факту походження дитини (відносин усиновлення) і полягає у задоволенні сукупності необхідних життєвих потреб в їжі, житлі, навчанні, професії, співмірних страхуванню на випадок хвороби або на випадок виникнення потреби в догляді (§ 1578, 1610 Цивільного кодексу Німеччини). Утримання повнолітніх дітей залежить не тільки від віку, але і від настання ix самостійності у фінансовому плані i припиняється, коли дитина отримує можливість самостійно заробляти та утримувати себе.
Підставами для сплати батьками аліментів на утримання дитини $є$ : 1) потреба в матеріальній допомозі і відсутність джерел існування в дитини; 2) можливість з боку батьків здійснювати обов'язок щодо утримання без шкоди власному матеріальному становищу і становищу інших осіб, яких батьки утримують [6].

Італійський термін "alimenti" співзвучний терміну «аліменти», що застосовується Сімейним кодексом України. Стаття 29 Конституції Італії зазначає, що Республіка гарантує права сім”і як природного союзу, заснованого на шлюбі; ст. 30 визначає, що батьки зобов'язані і мають право утримувати, навчати і виховувати дітей, навіть якщо вони народжені поза шлюбом [12].

Стаття 155 Цивільного кодексу Італіі робить акцент на здійсненні безпосередньо виплат, які б задовольняли різні потреби дитини (освіта, культура, спорт, охорона здоров'я та ін.), а не на стягнення аліментів. Цивільне законодавство Італії (ч. 3 ст. 155 ЦК Італіі) дозволяє самостійно вирішувати тому з батьків, хто бажає витратити кошти в інтересах своєї дитини, не погоджуючи свої дії з іншим з батьків і не звертаючись до італійського суду.

Оскільки в практиці італійських шлюборозлучних процесів є 2 фази сепараційний i власне розлучення, то в кожному з цих періодів змінюються і обов'язки батьків, які визначаються судом. На стадії сепарації один з батьків на підставі ст. 507 KK Італії виплачує аліменти на дитину тільки в разі, якщо інший справді потребує фінансової підтримки. Якщо ж шлюб між батьками розірваний, то один з батьків зобов'язаний тому, з ким дитина проживає, виплачувати аліменти на дитину, якщо суддя виніс відповідну постанову в рішенні про розірвання шлюбу [13].

Отже, німецьке право виділяє дві вікові категорії повнолітніх дітей, які потребують отримання утримання від батьків; у німецькому законо- 
давстві передбачена можливість збереження права на утримання за працездатними повнолітніми дітьми; а також надані широкі можливості участі держави в поліпшенні матеріального становища сторін аліментного зобов'язання шляхом надання допомоги та окремих соціальних пільг. Італійське законодавства не акцентує увагу на стягнення аліментів, проте покликане забезпечити належний рівень життя та розвитку для дитини.

Дитина є найбільш вразливим учасником суспільних відносин, оскільки перебуває у матеріальній та соціальній залежності від батьків або осіб, які їх замінюють. Тому вона потребує особливого захисту та забезпечення реалізації своїх прав та свобод, становлення іï як особистості. Сімейні відносини з іноземним елементом $€$ явищем не рідкісним та вимагають до себе нестандартного підходу. Аліментні відносини у міжнародному приватному праві врегульовані Конвенцією ООН від 20 червня 1956 року про стягнення за кордоном аліментів; Гаазькою конвенцією від 24 жовтня 1956 року про право, що застосовується до аліментних зобов'язань стосовно дітей; Гаазькою конвенцією від 15 квітня 1958 про визнання та виконання рішень щодо аліментних зобов'язань стосовно дітей; Гаазькою конвенцією від 02 жовтня 1973 року про визнання і виконання рішень стосовно зобов'язань про утримання; Протоколом від 23 листопада 2007 року про право, що застосовується до аліментних відносин; Конвенцією ООН «Про права дитини» 1989 року; Регламентом Європейської ради № 4/2009 «Про юрисдикцію, застосовне право, визнання та виконання рішень, а також співробітництво в галузі аліментних зобов'язань». Вказані нормативні акти покликані врегулювати транскордонні аліментні відносини та забезпечити належне виконання аліментних зобов'язань.
Право дитини на рівень життя, необхіднии для ї̈ фізичного, розумового, духовного $i$ соиіального розвитку, забезпечується закріпленням обов'язків батьків щодо утримання. 3 огляду на зростання кількості шлюбів, що укладаються з іноземними громадянами та особами без громадянства, особливої актуальності набули проблеми стягнення аліментів у разі проживання подружжя в різних державах.

Незважаючи на безсумнівну необхідність міжнародного співробітниитвва у такій сфері, чимало держав не приєднані до жодної з конвенцій, що регулюють порядок стягнення аліментів у разі проживання платника в іншій державі. У статті розглянуті основні Конвенціі та порядок стягнення аліментів $у$ транскордонних відносинах.

Серед найважливіших міжнародних нормативних актів, що регулюють транскордонні аліментні відносини, є Конвенція ООН від 20 червня 1956 року про стягнення за кордоном аліментів; Гаазька конвенція від 24 жовтня 1956 року про право, що застосовується до аліментних зобов'язань стосовно дітей; Гаазька конвенція від 15 квітня 1958 про визнання та виконання рішень щодо аліментних зобов'язань стосовно дітей; Гаазька конвенція від 02 жовтня 1973 року про визнання $i$ виконання рішень стосовно зобов'язань про утримання; Протокол віо 23 листопада 2007 року про право, що застосовується до аліментних відносин; Конвенція ООН «Про права дитини» 1989 року; Регламент Європейської ради № 4/2009 «Про юрисдикцію, застосовне право, визнання та виконання рішень, а також співробітництво в галузі аліментних зобов'язань». Основні положення цих Конвенцій, що пропонують єдиний підхід до правового регулювання аліментних відносин, відносин щодо стягнення аліментів, розглянуті у статmі. 
Aліментні зобов'язання є однією з найбільш важливих категорій сучасного сімейного права. Сторонами аліментного зобов'язання e платник аліментів (особа, яка зобов'язана сплачувати аліменти) $i$ одержувач аліментів (особа, яка має право вимагати від платника сплати аліментів). Специфікою аліментних зобов'язань батьків щодо утримання неповнолітніх дітей $є$ виникнення таких правовідносин незалежно від будь-яких обставин, наприклад, втрати роботи особою, яка зобов'язана сплачувати аліменти, важке матеріальне становище, інші випадки відсутності у платника достатніх коштів на утримання дитини. У законодавстві закріплений абсолютний характер аліментних обов'язків батьків.

Ключові слова: аліменти, аліментні зобов'язання, утримання, дитина.

\section{Zastavna O. Regulation of aliment relations in transboard space}

The child's right to a standard of living necessary for his or her physical, mental, spiritual and social development is ensured by consolidating the parent's responsibility for maintenance. Given the growing number of marriages with foreign nationals and stateless persons, the problems of recovery of alimony during the residence of spouses in different countries have become especially relevant.

Despite the undoubted need for international cooperation in this area, many states are not party to any convention governing the recovery of alimony when the payer resides in another state. The article considers the main Conventions and the procedure for recovery of alimony in cross-border relations.

Among the most important international regulations governing cross-border alimony relations is the UN Convention of 20 June 1956 on the Recovery Abroad of Alimony; The Hague Convention of 24 October 1956 on the Law Applicable to Child Support Obligations; The Hague Convention of 15 April 1958 on the Recognition and Enforcement of Decisions concerning Child Support; Hague Convention of 2 October 1973 on the Recognition and Enforcement of Decisions Concerning Maintenance Obligations; Protocol of 23 November 2007 on the law applicable to alimony; UN Convention on the Rights of the Child 1989; European Council Regulation No. 4/2009 "On jurisdiction, applicable law, recognition and enforcement of decisions and cooperation in the field of maintenance obligations". The main provisions of these Conventions, which offer a unified approach to the legal regulation of alimony relations, relations on the recovery of alimony, are discussed in the article.

Aliment relations are one of the most important categories of modern family law. The parties to the alimony obligation are the payer of alimony (the person who is obliged to pay alimony) and the recipient of alimony (the person who has the right to demand payment of alimony from the payer). The specifics of parental alimony obligations for the maintenance of minor children are the emergence of these legal relations, regardless of any circumstances, such as loss of employment by a person who is obliged to pay alimony, financial difficulties, other cases of lack of sufficient funds for child support. The legislation enshrines the absolute nature of the maintenance obligations of parents.

Key words: alimony, alimony obligations, alimony, child.

\section{Лiтература}

1. Borras A., Degeling J. The Convention of 23 November 2007 on the International Recovery of Child Support and Other Forms of Family Maintenance: an explana- 


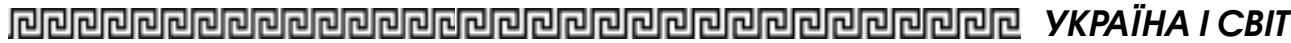

tory report. URL: https: / / assets.hcch.net/ upload/expl38.p (дата звернення: 31.01.2021)

2. Convention of 23 November 2007 on the International Recovery of Child Support and Other Forms of Family Maintenance. URL: https: / / www.hcch.net/en/instruments / conventions /status-table/?cid=131. (dama звернення: 31.01.2021).

3. Reichelt-Pahl. Die Aufgabe des staatlichen Kindergeld und sein Einfl uss auf den Unterhaltehelichen Kinder. Münster, 1991, $185 \mathrm{p}$.

4. Walker L. Maintenance and child support in private international law. Oxford: Hart Publishing. 2015. 126 p.

5. Галенська Л.Н. Стягнення аліментів за кордоном. Журнал міжнародного приватного права. 2009. № 1. С. 3-16;

6. Єрохіна Є.B. Європейське сімейне право : навчально-методичний посібник для студентів, що навчаються за програмами вищої освіти за напрямом підготовки 40.03.01 «Юриспруденція». Оренбург : ОДУ. 2016. 550 с.;

7. Євростат, «мігранти в Європі: Cтатистичний портрет першого $i$ другого покоління». 2011. С. 16. URL: шше. un.org / esa / population / migration / hld / Text/Migratio; www.un.org/migration/ presskit/pressrelease12sept.pdf (Jama звернення: 01.02.2021).

8. Конвениія ООН про права дитини від 21 грудня 1995 року. URL: https:// zakon.rada.gov.ua/laws / show/995_021\# Text (дата звернення: 10.01.2021).

9. Конвенція про визнання $i$ виконання рішень стосовно зобов'язань про утримання від 02 жовтня 1973 року. URL: https: / /zakon.rada.gov.ua/laws / show/973_001\#Text (дата звернення: 10.01.2021)

10. Муратова С.А., Костюченко О.Ю. Правове регулювання аліментних зобов'язань батьків стосовно непрацездатних $i$ які потребують матеріальної допомоги повнолітніх дітей. Вісник університету iм. O.E. Kутафіна, 2016. № 10 (26). C 84-92.

11.Про затвердження Інструкції про виконання в Україні Конвенції про стягнення аліментів за кордоном : Наказ Міністерства юстиції України від 29 грудня 2006 року № 121/5. URL: https: / / zakon.rada.gov.ua/laws / show/ 995_021\#Text (дата звернення: 15.01.2021)

12. Протокол «Про право, що підлягае застосуванню до аліментних зобов'язань» від 23 листопада 2007 рокy. URL: http: / / www.hcch.net/ index_en.php?act=conventions.text\& cid=133 (дата звернення: 15.01.2021).

13. Юридична допомога адвоката Франческо Грассо в Imaлiï. URL: http: / / www.studiolegalegrasso.net / ru / (дата звернення: 11.01.2021). 